\title{
Constraints Faced by Women Dairy Cooperative Society Members in Jaipur, Rajasthan, India
}

\author{
Virendra Singh", S.K. Rewani, Sunil Rajoria and G.R. Saini \\ Department of Veterinary and Animal Husbandry Extension Education, Post Graduate Institute \\ of Veterinary Education and Research, Jaipur- 302031, Rajasthan, India \\ *Corresponding author
}

\section{A B S T R A C T}

\begin{tabular}{|l|}
\hline Key wor d s \\
Constraints, Dairy \\
cooperative society, \\
Jaipur.
\end{tabular}

The present study was carried out in purposively selected Jaipur district of Rajasthan to evaluate constraints faced by Women Dairy Cooperative Society (WDCS) members. A sample size of 120 women farmers who were active members of women dairy cooperative societies were randomly selected for study. The data were collected through structured interview schedule. Major constraints recorded were lack of awareness about advantage and facilities provided by the Government and milk unions for rearing animals, lack of knowledge about the women rights for their empowerment, illiteracy, lack of affordability to purchase feed additives and concentrates, high cost of veterinary medicines and inequality in issuing loans. The study also revealed that economic constraints was ranked first with a mean score of 3.06 followed by technological constraints (2.87), infrastructural constraints (2.74), social constraints (2.73), political constraints (2.69), organizational constraints (2.62), psychological constraints (2.56) and personal constraints (2.54).

\section{Introduction}

Women play a vital role in the dairy sector of India. Women constitute 71 per cent of the labour force in livestock sector as against 35 per cent in crop farming (Sigh et al., 2015). Even though women in rural areas work long hours in and outside the household, e.g. in fuel and fodder collection, fetching water and taking care of animals, their work is often neglected and made invisible in official statistics as it is not paid wage labour (Bennett, 1992). Dairy cooperatives have provided a platform to women to demonstrate their capabilities and competence through their activities. They were exclusively of women demonstrated that gender based interventions in its programmes planning not only increased income and employment, but also enhanced women's status in family and society. Women focused approach were advocated as a part of the strategy under which sufficient number of women dairy cooperatives societies were formed at village level with the point of view that would provide a source of additional income and an organized platform to seek personal, social and other grievances (Niketha et al., 2017). The Rajasthan state has total 13,492 registered dairy cooperative societies in which $5,159(38.24 \%)$ are women dairy cooperative societies (Anonymous, 2016).Women Farmers face various hurdles in dairying which includes social, personal, 
psychological, economic, political, technological, organizational and infrastructural constraints. Hence, to study the problems faced by the women dairy farmers, this research work was taken up with the objective to delineate the various constraints faced by the women farmers.

\section{Materials and Methods}

The present study was conducted in purposively selected Jaipur district of Rajasthan owing to prospective rate of dairying, good cooperative network, livestock wealth status and large numbers of dairy cooperatives. Four tehsils viz. Amber, Chaksu, Chomu and Phagi were selected randomly from Jaipur district and two villages were selected randomly from each tehsils. From each village, 15 women who were active members of WDCS for at least three years were selected randomly.

Thus, total 120 respondents were selected for the study. The ex-post facto research design was followed. The data was collected by using a structured interview schedule. The identified constraints were measured on a four point continuum viz. most serious constraint, serious constraint, less serious constraint and not a constraint respectively. The Statistical measures such as percentage, frequency and mean score were used.

\section{Results and Discussion}

The constraints have been divided into eight major categories and the responses of women farmers were expressed as frequency and percentage.

\section{Social constraints}

Among various social constraints, pressurization of family members for taking loan for household needs or unproductive purposes, lack of support from family members to join WDCS activities and lack of support from family to participate in cultural and community activities were perceived as 'serious constraint' by $35.00,36.67$ and 34.17 per cent while, 'less serious constraint' by $27.50, \quad 33.33$ and 31.67 per cent of respondents, respectively.

While, low social acceptability for participation in WDCS and no freedom of women of the family for spending their income independently were felt as 'serious constraint' by 40.00 and 41.67 per cent while, 'less serious constraint' by 31.67 and 27.50 per cent of respondents, respectively.

Lack of systematic effort for addressing social issues and lack of knowledge about the women rights for their empowerment were considered as 'most serious constraint' by 45.00 and 60.83 per cent while, 'serious constraint' by 40.83 and 26.67 per cent of respondents, respectively. Dependence on family members for supplying milk was recognized as 'serious constraint' by 54.17 per cent while 'most serious constraint' by 27.50 per cent of respondents. Further, it was found that non-cooperative attitude of husband or in-laws were recognized as 'less serious constraint' and 'not a constraint' by 43.33 per cent and 26.67 per cent respondents, respectively (Table 1).

\section{Personal constraints}

Regarding Personal constraints, increased work burden and responsibility and hindrance due to ill health were perceived as 'less serious constraint' by 41.67 per cent and 40.00 per cent while, 'serious constraint' by 29.17 per cent and 30 per cent of respondents, respectively. Illiteracy was recognized as 'most serious constraint' by 56.67 per cent and 'serious constraint' by 23.33 per cent respondents (Table 1). 


\section{Psychological constraints}

Referring to psychological constraints, poor involvement of members in decision making activities in WDCS and lack of motivations among members were perceived as 'most serious constraint' by 28.33 and 33.33 per cent while, 'serious constraint' by 25.00 and 23.33 per cent of respondents, respectively. While, excessive stress and tension of dual responsibility and multi-purpose work load were recognized as 'serious constraint' by 36.67 per cent and 40.00 per cent and 'less serious constraint' by 29.17 per cent and 25.53 per cent of respondents, respectively. It was further reported that lack of selfconfidence was recognized as 'serious constraint' by majority of the respondents $(38.33 \%)$ followed by 'most serious constraint' $(31.67 \%)$.

\section{Political constraints}

About political constraints, lack of interest in political activities and lack of effort for creating political awareness among women were perceived as 'serious constraint' by 35.83 per cent and 30.00 per cent while, 'less serious constraint' by 30.83 per cent and 23.33 per cent of respondents, respectively.

Vitiation of political affiliation in the working environment of WDCS societies and lack of effective leadership among WDCS members were considered as 'most serious constraint' by 41.67 per cent and 30.00 per cent of respondents, respectively (Table 1).

\section{Economic constraints}

Referring to economic constraints, lack of affordability to purchase feed additives \& concentrates, high cost of veterinary medicines and high charges for emergency services, inequality in issuing loans and low income from dairying were perceived as 'most serious constraint' by 56.67 per cent, 51.67 per cent, 41.67 per cent, 51.67 and 48.33 per cent while, 'serious constraint' by 32.50 per cent, 30.83 per cent, 33.33 , per cent 32.50 per cent and 35.83 per cent of respondents, respectively. While, improper utilization of WDCS funds and non-sharing of information with members about transactions and financial activities in WDCS were recognized as 'serious constraint' by 34.17 per cent and 45.83 per cent and 'less serious constraint's by 28.33 per cent and 38.33 per cent of respondents, respectively. High charge of A.I. was recognized as 'serious constraint' by 35.83 per cent and 'most serious constraint' by 32.50 per cent respondents (Table 1).

\section{Technological constraints}

Regarding technological constraints, lack of awareness about advantage and facilities provided by the Govt. and milk unions for rearing animals, poor skilled staff at A.I. centers and unavailability of high yielding animals were felt as 'most serious constraint' by 61.67 per cent, 35.67 per cent and 45.50 per cent respondents, respectively. Among the 'serious constraints' were lack of technical training for growing green fodder $(45.00 \%)$ and technical inability in handling ICT tools $(42.50 \%)$. Inadequate availability of fodder seeds and lack of high yielding varieties (HYV) in fodder crops were recognized as 'less serious constraint' by 42.50 per cent and 38.33 per cent while, 'serious constraint' by 30.83 per cent and 26.67 per cent of respondents, respectively (Table 1).

\section{Organizational constraints}

Concerning to organizational constraints, lack of cooperation among WDCS members, inappropriate distribution of benefits and inadequate profit from WDCS activities were perceived as 'serious constraint' by 41.67 per 
cent, 42.50 per cent and 35.83 per cent while, 'less serious constraint' by 30.83 per cent, 33.33 per cent and 29.17 per cent of respondents, respectively. Non-maintenance of proper accounts was perceived as 'most serious constraint' and 'serious constraint' by
39.17 per cent and 32.50 per cent of respondents, respectively. Further, 49.17 per cent of respondents felt that long duration of meeting was 'not a constraint' while it was a 'less serious constraint' for 39.17 per cent respondents (Table 1).

Table.1 Distribution of the WDCS members on the basis of their constraints $(n=120)$

\begin{tabular}{|c|c|c|c|c|c|c|c|c|c|}
\hline \multirow{2}{*}{ Sl. No. } & \multirow{2}{*}{ Constraints } & \multicolumn{2}{|c|}{ MSC } & \multicolumn{2}{|c|}{ SC } & \multicolumn{2}{|c|}{ LSC } & \multicolumn{2}{|c|}{$\mathrm{NC}$} \\
\hline & & $f$ & $\%$ & $f$ & $\%$ & $f$ & $\%$ & $f$ & $\%$ \\
\hline $\mathbf{A}$ & Social & & & & & & & & \\
\hline 1 & $\begin{array}{l}\text { Family members used to pressurize to take } \\
\text { loan for household needs or unproductive } \\
\text { purposes }\end{array}$ & 11 & 9.17 & 42 & 35.00 & 33 & 27.50 & 34 & 28.33 \\
\hline 2 & $\begin{array}{l}\text { Lack of support from family members to join } \\
\text { WDCS activities }\end{array}$ & 4 & 3.33 & 44 & 36.67 & 40 & 33.33 & 32 & 26.67 \\
\hline 3 & $\begin{array}{l}\text { Lack of support from family to participate in } \\
\text { cultural and community activities }\end{array}$ & 11 & 9.17 & 41 & 34.17 & 38 & 31.67 & 30 & 25.00 \\
\hline 4 & $\begin{array}{l}\text { Non-cooperative attitude of husband or in- } \\
\text { laws }\end{array}$ & 7 & 5.83 & 29 & 24.17 & 52 & 43.33 & 32 & 26.67 \\
\hline 5 & $\begin{array}{l}\text { Dependence on family members for } \\
\text { supplying milk }\end{array}$ & 33 & 27.50 & 65 & 54.17 & 18 & 15.00 & 4 & 3.33 \\
\hline 6 & $\begin{array}{l}\text { Low social acceptability for participation in } \\
\text { WDCS }\end{array}$ & 7 & 5.83 & 48 & 40.00 & 38 & 31.67 & 27 & 22.50 \\
\hline 7 & $\begin{array}{l}\text { Women of the family are not free to spend } \\
\text { their income independently }\end{array}$ & 29 & 24.17 & 50 & 41.67 & 33 & 27.50 & 8 & 6.67 \\
\hline 8 & $\begin{array}{l}\text { Lack of systematic effort for addressing } \\
\text { social issues }\end{array}$ & 54 & 45.00 & 49 & 40.83 & 15 & 12.50 & 2 & 1.67 \\
\hline 9 & $\begin{array}{l}\text { Lack of knowledge about the women rights } \\
\text { for their empowerment }\end{array}$ & 73 & 60.83 & 32 & 26.67 & 14 & 11.67 & 1 & 0.83 \\
\hline B & Personal & & & & & & & & \\
\hline 1 & Increased work burden and responsibility & 8 & 6.67 & 35 & 29.17 & 50 & 41.67 & 27 & 22.50 \\
\hline 2 & Hindrance due to ill health & 4 & 3.33 & 36 & 30.00 & 48 & 40.00 & 32 & 26.67 \\
\hline 3 & Illiteracy & 68 & 56.67 & 28 & 23.33 & 18 & 15.00 & 6 & 5.00 \\
\hline $\mathbf{C}$ & Psychological & & & & & & & & \\
\hline 1 & Multipurpose work load & 12 & 10.00 & 48 & 40.00 & 31 & 25.53 & 29 & 24.17 \\
\hline 2 & $\begin{array}{l}\text { Poor involvement of members in decision } \\
\text { making activities in WDCS }\end{array}$ & 34 & 28.33 & 30 & 25.00 & 28 & 23.33 & 28 & 23.33 \\
\hline 3 & Lack of motivations among members & 40 & 33.33 & 28 & 23.33 & 23 & 19.17 & 29 & 24.17 \\
\hline 4 & $\begin{array}{l}\text { Excessive stress and tension of dual } \\
\text { responsibility }\end{array}$ & 10 & 8.33 & 44 & 36.67 & 35 & 29.17 & 31 & 25.83 \\
\hline 5 & Lack of self confidence & 38 & 31.67 & 46 & 38.33 & 24 & 20.00 & 12 & 10.00 \\
\hline D & Political & & & & & & & & \\
\hline 1 & Lack of interest in political activities & 23 & 19.17 & 43 & 35.83 & 37 & 30.83 & 17 & 14.16 \\
\hline
\end{tabular}




\begin{tabular}{|c|c|c|c|c|c|c|c|c|c|}
\hline 2 & $\begin{array}{l}\text { Lack of effort for creating political awareness } \\
\text { among women }\end{array}$ & 32 & 26.67 & 36 & 30.00 & 28 & 23.33 & 24 & 20.00 \\
\hline 3 & $\begin{array}{l}\text { Political affiliation vitiate in the working } \\
\text { environment of WDCS }\end{array}$ & 50 & 41.67 & 28 & 23.33 & 29 & 24.17 & 13 & 10.83 \\
\hline 4 & $\begin{array}{l}\text { Lack of effective leadership among WDCS } \\
\text { members }\end{array}$ & 36 & 30.00 & 26 & 21.67 & 27 & 22.50 & 31 & 25.83 \\
\hline $\mathbf{E}$ & \multicolumn{9}{|l|}{ Economic } \\
\hline 1 & Improper utilization of WDCS funds & 16 & 13.33 & 41 & 34.17 & 34 & 28.33 & 29 & 24.17 \\
\hline 2 & Inequality in issuing loans & 62 & 51.67 & 39 & 32.50 & 17 & 14.17 & 2 & 1.67 \\
\hline 3 & $\begin{array}{l}\text { Information about transactions and financial } \\
\text { activities in WDCS are not shared with } \\
\text { members }\end{array}$ & 13 & 10.83 & 55 & 45.83 & 46 & 38.33 & 6 & 5.00 \\
\hline 4 & Low income from dairying & 58 & 48.33 & 43 & 35.83 & 14 & 11.67 & 5 & 4.17 \\
\hline 5 & A.I. charges are high & 39 & 32.50 & 43 & 35.83 & 34 & 28.33 & 4 & 3.33 \\
\hline 6 & High charges for emergency services & 50 & 41.67 & 40 & 33.33 & 23 & 19.17 & 7 & 5.83 \\
\hline 7 & $\begin{array}{l}\text { Lack of affordability to purchase feed } \\
\text { additives \& concentrates }\end{array}$ & 68 & 56.67 & 39 & 32.50 & 9 & 7.50 & 4 & 3.33 \\
\hline 8 & High cost of veterinary medicines & 62 & 51.67 & 37 & 30.83 & 19 & 15.83 & 2 & 1.67 \\
\hline $\mathbf{F}$ & \multicolumn{9}{|l|}{ Technological } \\
\hline 1 & $\begin{array}{l}\text { Lack of awareness about advantage and } \\
\text { facilities provided by the Govt. and milk } \\
\text { unions for rearing animals }\end{array}$ & 74 & 61.67 & 27 & 22.50 & 18 & 15.00 & 1 & 0.83 \\
\hline 2 & $\begin{array}{l}\text { Lack of technical training for growing green } \\
\text { fodder }\end{array}$ & 17 & 14.17 & 54 & 45.00 & 40 & 33.33 & 9 & 7.50 \\
\hline 3 & Inadequate availability of fodder seeds & 12 & 10.00 & 37 & 30.83 & 51 & 42.50 & 20 & 16.67 \\
\hline 4 & Technical inability in handling ICT tools & 45 & 37.50 & 51 & 42.50 & 19 & 15.83 & 5 & 4.17 \\
\hline 5 & $\begin{array}{l}\text { Lack of high yielding varieties (HYV) in } \\
\text { fodder crops }\end{array}$ & 17 & 14.17 & 32 & 26.67 & 46 & 38.33 & 25 & 20.83 \\
\hline 6 & Poor skilled staff at A.I. centers & 44 & 35.67 & 23 & 19.17 & 31 & 25.83 & 22 & 18.33 \\
\hline 7 & Unavailability of high yielding animals & 57 & 45.50 & 42 & 35.00 & 21 & 17.50 & 0 & 0.00 \\
\hline G & \multicolumn{9}{|l|}{ Organizational } \\
\hline 1 & Lack of cooperation among WDCS members & 27 & 22.50 & 50 & 41.67 & 37 & 30.83 & 6 & 5.00 \\
\hline 2 & Inappropriate distribution of benefits & 19 & 15.83 & 51 & 42.50 & 40 & 33.33 & 10 & 8.33 \\
\hline 3 & Proper accounts are not maintained & 47 & 39.17 & 39 & 32.50 & 24 & 20.00 & 10 & 8.33 \\
\hline 4 & Inadequate profit from WDCS activities & 37 & 30.83 & 43 & 35.83 & 35 & 29.17 & 5 & 4.17 \\
\hline 5 & Duration of meeting is too long & 5 & 4.17 & 9 & 7.50 & 47 & 39.17 & 59 & 49.17 \\
\hline $\mathbf{H}$ & \multicolumn{9}{|l|}{ Infrastructural } \\
\hline 1 & Inadequate space for office of WDCS & 59 & 49.17 & 26 & 21.67 & 28 & 23.33 & 7 & 5.83 \\
\hline 2 & Distant location of WDCS & 9 & 7.50 & 29 & 24.17 & 46 & 38.33 & 36 & 30.00 \\
\hline 3 & Lack of physical facilities at meeting place & 35 & 29.17 & 53 & 44.17 & 28 & 23.33 & 4 & 3.33 \\
\hline 4 & A.I. centers are located at distant places & 43 & 35.83 & 24 & 20.00 & 31 & 25.83 & 22 & 18.33 \\
\hline
\end{tabular}

MSC- Most Serious ConstraintSC- Serious Constraint LSC- Less Serious Constraint NC-Not a Constraint 
Table.2 Constraints perceived by WDCS members

\begin{tabular}{|c|l|c|c|}
\hline Sl. No. & \multicolumn{1}{|c|}{ Constraints } & Mean score & Position \\
\hline 1 & Social constraints & 2.73 & $4^{\text {th }}$ \\
\hline 2 & Personal constraints & 2.54 & $8^{\text {th }}$ \\
\hline 3 & Psychological constraints & 2.56 & $7^{\text {th }}$ \\
\hline 4 & Economic constraints & 3.06 & $1^{\text {st }}$ \\
\hline 5 & Political constraints & 2.69 & $5^{\text {th }}$ \\
\hline 6 & Technological constraints & 2.87 & $2^{\text {nd }}$ \\
\hline 7 & Organizational constraints & 2.62 & $6^{\text {th }}$ \\
\hline 8 & Infrastructural constraints & 2.74 & $3^{\text {rd }}$ \\
\hline
\end{tabular}

\section{Infrastructural constraints}

Between various infrastructural constraints, inadequate space for office of WDCS and distant location of A.I. centers were perceived as 'most serious constraint' by 49.17 per cent and 35.83 per cent while, 'less serious constraint' by 23.33 per cent and 25.83 per cent of respondents, respectively.

While, distant location of WDCS was recognized as 'less serious constraint' and 'not a constraint by 38.33 per cent and 30.00 per cent of respondents, respectively. Further, lack of physical facilities at meeting place was felt as 'serious constraint' and 'most serious constraint' by 44.17 per cent and 29.17 per cent of respondents, respectively (Table 1).

Table 2 indicates that economic constraints was ranked first with a mean score of 3.06 followed by technological constraints (2.87), infrastructural constraints (2.74), social constraints (2.73), political constraints (2.69), organizational constraints (2.62), psychological constraints (2.56) and personal constraints (2.54) in that order.

Present findings are in agreement with the findings of Chaudhary et al., (2013), Patel et al., (2013), Rathod et al., (2012), Singh et al., (2012) and Patil et al., (2009) who have reported similar constraints perceived by dairy farmers. The present study helped us to derive the conclusion that lack of awareness about advantage and facilities provided by the Government and milk unions for rearing animals, lack of knowledge about the women rights for their empowerment, illiteracy, lack of affordability to purchase feed additives and concentrates, high cost of veterinary medicines and inequality in issuing loans were perceived as most serious constraints. While, dependence on family members for supplying milk, information about transactions, financial activities in WDCS are not shared with members, lack of technical training for growing green fodder, lack of physical facilities at meeting place, technical inability in handling ICT Tools and inappropriate distribution of benefits were recognized as serious constraints encountered by women farmers through dairy cooperative.

\section{Acknowledgement}

I am thankful to the Women Dairy Cooperative Society members who provided valuable informations for the study.

\section{References}

Anonymous, 2016. Annual Report 2014-15. Rajasthan Cooperative Dairy Federation Limited (RCDF), Jaipur, Rajasthan.

Bennett, L. 1992. Women, Poverty and Productivity in India. Economic 
Development Institute seminar paper no. 43. World Bank, Washington.

Chaudhary, M., Singh, M.P. and Sharma, K.C., 2013. Constraints Faced by Farm Women in Adoption of Improved Cattle Management Practices in arid Rajasthan. Indian Journal of Extension Education \& Rural Development, 21: 153-158.

Niketha, L., Sankhala, G., Prasad, K. and Kumar, S., 2017. Empowerment of Women through Dairy Cooperatives in Karnataka, India.International Journal of Current Microbiology and Applied Sciences, 6(7): 1292-1304.

Patel, N.B., Saiyed, L.H., Rao, T.K.S.,Rana, Ranjeetsingh, Modi, R.J. and Sabapara, G.P., 2013.Status and Constraints of Dairying in The Tribal Households of Narmada Valley of Gujarat - India. Animal Science Reporter, 7(3): 83-86.

Rathod, P., Nikam, T.R., Landge, S. and
Hatey, A., 2012.Perceived Constraints in Livestock Service Delivery by Dairy Cooperatives: A Case Study of Western Maharashtra, India. Indian Journal of Dairy Science, 65(5): 423-429.

Singh, A.S., Singh, K., Chakravarty, R., Vairagar and Kumar, C., 2012. Constraints perceived by members of Manipur (India) milk producers' cooperative union in practicing improved dairy farming. Journal of Dairying Foods and Home Sciences, 31(4): 279 - 283.

Singh, U., Avinashilingam, N.A. Vijay, Malik, B.S., 2015. Constraints Perceived by Members and Nonmembers about Women Dairy Cooperative Societies in Haryana. Indian Journal of Extension Education, 48(3\&4): 118-120.

\section{How to cite this article:}

Virendra Singh, S.K. Rewani, Sunil Rajoria and Saini, G.R. 2017. Constraints Faced by Women Dairy Cooperative Society Members in Jaipur, Rajasthan, India. Int.J.Curr.Microbiol.App.Sci. 6(12): 2612-2618. doi: https://doi.org/10.20546/ijcmas.2017.612.302 